\title{
Identifying the Components and Importance of Intellectual Capital in Knowledge-Intensive Organizations
}

\author{
Muhammad Wasim Jan Khan \\ PhD Scholar, Faculty of Economics and Business \\ Universiti Malaysia, Sarawak, Malaysia \\ E-mail:wasimjanpk@yahoo.com
}

Received: October 25, 2014 Accepted: November 6, 2014

doi:10.5296/ber.v4i2.6594 URL: http://dx.doi.org/10.5296/ber.v4i2.6594

\begin{abstract}
Intellectual capital is considered as one of the vita strategic assets for the success and sustainability of the organization in a competitive business environment. Intellectual capital is also recognized as the most crucial asset for the survival of knowledge intensive organizations. The aim of this study is to explore the components of intellectual in order to comprehend the concept and applications of intellectual capital indepth. Subsequently, to fulfill the objective of this study a comprehensive related literature review was performed. The related literature showed that there are six components of intellectual capital namely human capital, customer capital, structural capital, social capital, technological capital and spiritual capital have been identified.
\end{abstract}

Keywords: Intellectual capital, Literature review, Components

\section{Introduction to Intellectual Capital}

It is well perceived that intellectual capital is the lever for organizations to acquire sustainable performance and competitive advantage (Cohen \& Kaimenakis, 2007; Ross and Ross, 1997). Intellectual capital is a main source for organizations in a knowledge-based economy, to gain competitive advantage and is a main pillar of knowledge-based economy. Intellectual capital management leads management to make appropriate operation decisions, appropriate investment, and management of the organizations and in achieving competitive edge (Shaari et al., 2011). For organizations intellectual capital has been regarded as a important source of competitive advantage, which influences the level of creativity and innovativeness (Taliyang et al., 2011). 


\section{Mll Macrothink}

Business and Economic Research

ISSN 2162-4860

2014, Vol. 4, No. 2

Research in the different aspects of intellectual capital is still relatively new (Goh \& Lim, 2004). Since the beginning of research in the early 1980s in the field of intellectual capital, there are numerous definitions for intellectual capital (Goh, 2005). Different concepts are proposed in the academia and each try to capture a particular phenomenon given the intangible nature of knowledge. It is realized by successful companies that investing in knowledge is essential to their ability to create high value products and services (Chang \& Hsieh, 2011).

Sustainable competitive advantage is mainly based on knowledge assets. The rapidly growing field of intellectual capital is an existing area of interest for both the researchers and practitioners (Bontis, 2001). The field of intellectual capital is developing into a diverse and multidisciplinary field which contains multiple meanings, methods and concepts, and it is supported to be knowledge generation and knowledge about knowledge (Jorgensen, 2006).

All business leaders should think about their attitudes again and again on intangible assets. They must appreciate and recognize the strategically managed knowledge and its measurement, and this they can make the difference between mediocrity and excellence in their organizations (Bontis, 1998). For successful competition in today's world economies it is absolutely necessary for organizations to understand and properly manage their intellectual capital if they want to succeed (Bhartesh \& Bandyopadhyay, 2005). Undoubtedly, in the emerging knowledge-driven economies of the world, many economies; like countries of European Union, UK, Scotland and many other emerging economies are also looking for strategies to reposition themselves, in today's world of the emerging knowledge-driven economies (Goh, 2005).

Nowadays organizations around the world are facing big challenges to make their knowledge more productive as a competitive resource in a complex and unpredictable environment (Daud $\&$ Yusoff, 2011). To gain sustainable competitive advantage in organizations intellectual capital is recognized as one of the most important asset. In western the concept intellectual capital was introduced for the first time. In organization is of Eastern countries the concept of intellectual capital is still quite new. Future research should apply intellectual capital model and examine the impact of intellectual capital on organizations (Khalique et al., 2011).

The term intellectual capital was first introduced by Jon Kenneth Galbraith in 1969 (Khalique et al 2011; \& Chang \& Hsieh, 2010). The word "intellectual" actually refers to the employees who encapsulate the company's knowledge. The conceptualization of IC may be broadened to include all value creation activities performed by humans; that is, the intelligent living organism: employees, directors and stakeholders relating to the company" (Chan, 2009).

Intellectual capital has been considered by many, defined by some, understood by a select few, and formally valued by practically no one (Sveiby, 1997). Intellectual capital has been rarely understood or studied. For organizations; intellectual capital is considered as an essential source to gain competitive advantage (Bontis 1998). Similarly it is argued that, unfortunately there is generally no accepted definition of intellectual capital (Chang and Hsieh, 2011). In modern economies for success and competitive advantage of organizations, intellectual capital is increasingly recognized as critical strategic asset (Khalique et al., 2013).

According to brooking (1996), intellectual capital is term given to the combined intangible 
assets of market, intellectual property, human centered and infrastructure, which enable the company to function (Bontis et al., 2000). The major contribution of Stewart's (1997); to the field of intellectual capital is to give the definition of intellectual capital and the recognition of the difficulty to measure intellectual capital (Bontis, 1998).

Stewart (1997) extended definition of intellectual capital with addition of customer capital and defined intellectual capital as the combination of human capital, structural capital and customer capital. Furthermore, intellectual capital consists of three components namely human capital, structural capital customer capital, and intellectual capital also have various intangible resources such as knowledge, education, employees competences, skills, intellectual agility, customer relationships, brand names and organizational structure (Kujansivu, 2009; Bontis et al., 2000; Bontis, 1998; Roos et al., 1997; Sveiby, 1997; \& Edvinsson, 1997). Intellectual capital is defined as the sum of structural capital and human capital (Edvinsson, 1997). Intellectual capital means individual workers' and organizational knowledge that contributed to sustainable competitive advantage (Bontis, 2001).

The Intellectual Capital management can be defined as the management of the expansion, enhancement and value evaluation of knowledge management, taking the knowledge management as the core, taking the enhancement of enterprise value as the intention under the condition adapting with the development strategy of the enterprise (Ding \& Li, 2010). According to Kozak, (2011) the concept of intellectual capital is still underdevelopment and there is still no uniform definition accepted for identifying the subcomponents of intellectual capital. Intellectual capital is defined as intangible assets including technology, customer information, brand name, reputation and corporate culture (Taliyang et al., 2011). From a strategic point of view in organizations, intellectual capital is linked to the organizations' knowledge ability to create and apply the potentially for creating value. The three/ key characteristics of intellectual capital can be described as follows; 1) Its intangibility 2) Its potential to create value 3) The growth effect of collective practice and synergies (Martin-de-Castro et al., 2011).

Intellectual capital does not include intellectual property. Intellectual property is the asset that includes copyrights, semiconductor topography rights, various design rights and patents. These also include trade and service marks (Bontis, 1998). Khalique et al (2013) argued that intellectual capital is having six/6 main components known as the (1) Human Capital, (2) Customer Capital, (3) Structural Capital, (4) Social Capital, (5) Technological Capital, and (6) Spiritual Capital.

Hence based on the above discussions and most specifically according to contribution of Khalique et al., (2013) to the field of intellectual capital; we can also define intellectual capital as "the most critical driver and strategic intangible asset for type of organization and the knowledge embedded in its main six/6 components known as (1) Human Capital, (2) Customer Capital, (3) Structural Capital, (4) Social Capital, (5) Technological Capital, and (6) Spiritual Capital". We further argue that beside any other physical and intangible asset intellectual capital is very much important for any type of organization and can play the basic role in achieving competitive advantage. Further we can also list intellectual capital as the back bone 
of any type of organization and studies should be encouraged in the field of intellectual capital.

\subsection{Human Capital}

Human capital represents the stock of individual knowledge of an organization and is represented by its employees (Bontis et al., 2000). For organizations human capital is very much important as it is a source of strategic renewal and innovation, whether it is in any form (Bontis, 1999). Human capital is the main source of intellectual capital creation in the enterprise (Shaari et al., 2011; Roos \& Roos, 1997). An American Nobel Prize-winning economist Theodore W. Schultz (1981) also used the term human capital and argued that: The decisive factors of production in improving the welfare of poor people are not space, energy, and cropland; the decisive factors are the improvement in population quality and advances in knowledge. These advancements can be augmented by appropriate investment in human capital (Bontis 1998). Human capital is considered as the main component of intellectual capital, human capital is based on employees' knowledge, skills, competencies, capability and innovation (Isaac et al., 2010; Shaari et al., 2011; Choo \& Bontis, 2002; Bontis et al., 2000; Bontis 1998; \& Edvinson \& Malone, 1997). We basically mean by human capital the knowledge acquired by a person which increases the value of his contribution to the firm and his own productivity (professional qualifications) (Fernandez et al., 2000).

In new venture as well as large organizations seeking to establish or maintain a competitive advantage and to act entrepreneurially, the application of knowledge, these actions required for the organizations need the use of intellectual capital embedded in the firm's managers and employees; thus it is the human capital which is required and necessary to take actions in organizations (Ireland et al., 2003). Human capital is recognized as the heart of intellectual capital (Khalique et al., 2011). Human capital includes various abilities, skills and knowledge possessed by the employees of the enterprises to contribute in the sustainable development (Khalique et al., 2011; Ding \& Li, 2010). Human capital has been defined by (Dess \& Lumpkin, (2001); as the "individual capabilities, knowledge, skill, and experience of the company's employees and managers, as they are relevant to the task at hand, as well as the capacity to add to this reservoir of knowledge, skills, and experience through individual learning", whereas According to Hitt et al., (2002), Human capital is the knowledge and skills of the firm's entire workforce (Ireland et al., 2003).

Intellectual agility enables one to change practices and to think of innovative solutions to problems. Even though in learning organizations, employees are considered the most important corporate assets, they are not owned by the organizations. There is still tremendous argument that when the new knowledge is generated by employees, then whether it belongs to company or not (i.e. while at home on the weekend a software programmer develops code, but yet the company still lays the claim to this codified knowledge) (Bontis et al., 2000). Human capital is the most important sources for organizations in achieving sustainable competitive advantages (Ireland et al., 2003). A progressively developing Asian country like Malaysia has to effectively transfer from an input-driven to knowledge-driven economy to be competitive in the global market that focuses more on utilizing human knowledge and skills, rather than on production of labor-intensive goods (Goh, 2005). 


\subsection{Customer Capital}

Customer capital is the another main component of intellectual capital and it is mainly based on the relationships between the enterprise and its customers (Shaari et al., 2011; Tai-Ning et al., 2011; \& Edvinson \& Malone, 1997). For organizations having good relations with its customers is very important, to enjoy competitive advantage (Roos et al., 2001). The scope of customer capital lies external to the human capital and external to the firm nodes. Customer capital of an organization is based on the knowledge embedded in its customers, suppliers, the government or related industry associations and its customer's relations (Bontis et al., 2000; Bontis, 1999; Bontis, 1998). There is no ambiguity that for any organization the main source of revenue generation is its customers; therefore, it is obligatory for an organization to make good relations with its customers and to win its customers by satisfying their need (Tai-Ning et al., 2011).

\subsection{Structural Capital}

Structural capital is considered as glue for organizations (Khalique et al., 2013). Structural capital consists of all the non-human stores of knowledge that includes data-bases, processes, organizational charts, strategies, process manuals, routines and policies (Wu \& Tsai, 2005; Bontis et al., 2000). According to Roos et al., (1997), structural capital of an organization is known as "what remains in the company when employees go home for the night". An organization with strong structural capital will have a supportive culture that allows individuals to try things, to fail, to learn, and to try again. The structural capital of an organization; is the knowledge embedded within its routines. The scope of structural capital lies internal to the firm but external to the human capital nodes. Structural capital is the critical link that allows us to measure intellectual capital in an organization (Bontis, 1998). Organizations can purchase or hire structural capital and organizations can share and duplicate structural capital also (Cohen $\&$ Kaimenakis, 2007). Structural capital deals with the structure and system of an organization. It plays an important role in an organization and helps in achieving competitive advantage by creating value added products and services (Ramezan, 2011).

\subsection{Social Capital}

Social capital is one the most important component of intellectual capital and it has significant contribution towards the firms' performances (Khalique et al., 2011; Bueno et al., 2004). Social capital is the most important sources for organizations in achieving sustainable competitive advantages (Ireland et al., 2003). All over the world, firms operating in global markets rarely have adequate resources to compete effectively in global markets, thus they access the needed resources through formal and informal relationships with other firms. Looking at the cultures in the world; compared to Western firms Asian countries have emphasized on relationships with other firms much more strongly (Hitt et al., 2002). Social networking relationships enable both family firms and non family firms to obtain the resources and capabilities that are used to organize strategic activities and create value (Acquaah, 2012). Social capital provides the flow of knowledge and information between types of networks (Inkpen \& Tsang, 2005). Social capital is the total set of information which benefits firms in value creation. Social capital is available both intra-firm and inter-firm relationships of firms 
(Koka \& Prescott, 2002). Social capital is the combination of relationships inside the firm and with external entities and helps organizations by absorbing knowledge to control and to gain access to resources (Nahapiet \& Ghoshal, 1998). Social capital is the set of relationships between individuals in an organization (internal social capital) and between individuals and organizations (external social capital) that facilitate actions (Hitt et al., 2002).

\subsection{Technological Capital}

A critical component of intellectual capital appeared in knowledge-based economy is Technological capital (Khalique et al., 2011). The key reason attributed to corporate success such as the tremendous "overvaluation" of high-technology companies is by leveraging knowledge (Bontis et al, 2000). Knowledge related to use of innovation of production techniques, access and product technology is the main base of technological capital, which is intangible and play an important role in the competitive success of firms (Fernandez et al., 2000).

Technological capital is the set of intangible assets which is based on innovation and technical process. Furthermore technological capital has positive impact on the performances of organizations and it is a significant contributor of intellectual capital (Bueno et al, 2006). Technological capital derives from technical knowledge; it is an intangible asset and is considered as important part of intellectual capital (Ramezan, 2011; Ramirez, 2010).

\subsection{Spiritual Capital}

Spiritual capital is also a vital component of intellectual capital (Ismail, 2005). Spiritual capital is based on spirit, influence, power and knowledge which can be derived from religion (Berger \& Hefinar, 2003). Spiritual capital is the power and influence that are created by a person or organization with the help of spiritual knowledge and religious beliefs (Liu, 2008).

Ismail (2005) introduced spiritual capital as an additional component of intellectual capital. He found in his study conducted in telecom sector in Malaysia that spiritual capital plays very important role in enhancing the organizational performance. According to Ismail (2005) Spiritual capital can be defined as "the intangible knowledge, faith and emotions embedded in the minds of individuals and in the hearts of organization which includes vision, direction, guidance, principles, values and culture".

The leader follow Gods will; by following divine laws or values in their daily lives and is considered as the spiritual capital and the spiritual resources can also be deployed in social context (Fry, 2003). Khalique et al., (2011) also argued that spiritual capital is mainly based on two dimensions as ethical values and religion.

\section{Conclusion}

The related literature showed that many researchers such as Bontis (2001); (Castro \& Delgado-Verde, 2012; Chen, Zhu, \& Xie, 2004; Cohen \& Kaimenakis, 2007; Khalique, Isa, \& Shaari, 2013; Khalique, Mansor, Isa, \& Shaari, 2014; Khalique, Shaari, \& Isa, 2013; Khalique, Shaari, Isa, \& Samad, 2013) revealed that intellectual capital is a most crucial asset for the success of organizations. Many studies for example (Khalique, 2012; Khalique \& Isa, 2014; 
Khalique, Isa, et al., 2013; Khalique, Shaari, \& Isa, 2014; Khalique, Shaari, Isa, et al., 2013) were conducted by using Integrated Intellectual capital Model (IICM). These studies affirmed that intellectual capital has significant impact on the performance of the organization. In addition, Khan and Khalique (2014) proposed an empirical study based on intellectual capital with strategic planning in Pakistani context. Similar studies are recommended for the potential researchers in intellectual capital field.

\section{References}

Acquaah, M. (2012). Social networking relationships, firms-specific managerial experience and firm performance in a transition economy: a comparative analysis of family owned and nonfamily firms. Research notes and commentaries. Strategic Management Journal, 33, 1215-1228. http://dx.doi.org/10.1002/smj.1973

Berger, P. L., \& Hefner, R. W. (2003). Spiritual capital in comparative perspective. Institute for the Study of Economic Culture, Institute on Religion and World Affairs, Boston University. Paper presented at the spiritual capital planning meeting, 10-11 October. Cambridge, Massachusetts. Also available at: http://www.metanexus.net/archive/spiritualcapitalresearchprogram/pdf/Berger.pdf

Bhartesh, K. R., \& Bandyopadhyay, A. K. (2005). Intellectual capital: concept and its $\begin{array}{llll}\text { measurement. } \quad \text { Finance } & \text { India, } & 19(4), & 1365-1374 .\end{array}$ http://dx.doi.org/10.1108/00251749810204142

Bontis, N. (1998). Intellectual capital; an exploratory study that develops measures and models. Management Decision, 36(2), 63-76.

Bontis, N. (1999). Managing organizational knowledge by diagnosing intellectual capital: framing and advancing the state of the field. International Journal of Technology Management, 18(5/6/7/8), 433-463. http://dx.doi.org/10.1504/IJTM.1999.002780

Bontis, N. (2001). Assessing knowledge assets: a review of the models used to measure intellectual capital. International Journal of Management Review, 3(1), 41-60. http://dx.doi.org/10.1111/1468-2370.00053

Bontis, N., Keow, W. C. C., \& Richardson, S. (2000). Intellectual capital and business performance in Malaysian industries. Journal of Intellectual Capital, 1(1), 85-100. http://dx.doi.org/10.1108/14691930010324188

Brooking, A. (1996). Intellectual Capital: Core Asset for the Third Millennium Enterprise, International Thomson Business Press, London.

Bueno, E. Salmador, M. P., \& Rodriguez, O. (2004). The role of social capital in today's economy; empirical evidence and proposal of new model of intellectual capital. Journal of Intellectual Capital, 5(4), 556-574. http://dx.doi.org/10.1108/14691930410567013

Bueno, E. Salmador, M. P., Rodriguez, O., \& Catro, G. M. D. (2006). Internal logic of intellectual capital: a biological approach. Journal of Intellectual Capital, 7(3), 394-405. http://dx.doi.org/10.1108/14691930410567013 


\section{Macrothink}

Business and Economic Research ISSN 2162-4860 2014, Vol. 4, No. 2

Castro, G. M. D., \& Delgado-Verde, M. (2012). Assessing Knowledge Assets in Technology-Intensive Firms: Proposing a Model of Intellectual Capital. Journal of CENTRUM Cathedra, 1(5), 43-59. http://dx.doi.org/10.7835/jcc-berj-2012-0066

Chan, K. H. (2009a). Impact of intellectual capital on organisational performance: an empirical study of companies in the Hang Seng Index (Part 1). The Learning Organization, 16(1), 4-21. http://dx.doi.org/10.1108/09696470910927641

Chang, W. S., \& Hsieh, J. (2010). The dynamics of Intellectual capital: taking organizational lifecycle into consideration. IEEE.

Chang, W. S., \& Hsieh, J. J. (2011). Intellectual capital and value creation-Is innovation capital a missing link? International Journal of Business and Management, 6(2), 3-12. http://dx.doi.org/10.5539/ijbm.v6n2p3

Chen, J., Zhu, Z., \& Xie, H. Y. (2004). Measuring intellectual capital: a new model and empirical study. Journal of Intellectual Capital, 5(1), 195-212. http://dx.doi.org/10.1108/14691930410513003

Choo, C. W., \& Bontis, N. (2002). The strategic management of intellectual capital and organizational knowledge. Oxford University Press, New York. USA.

Cohen, S., \& Kaimenakis, N. (2007). Intellectual capital and corporate performance in knowledge-intensive SMEs. The Learning Organization, 14(3), 241-262. http://dx.doi.org/10.1108/09696470710739417

Daud, S., \& Yusoff, W. F. W. (2011). How intellectual capital mediates the relationship between knowledge management processes and organizational performances. African Journal of Business Management, 5(7), 2607-2617.

Ding, Y., \& Li, G. (2010). Study on the management of intellectual capital. International Journal of Business and Management, 5(2), 213-216. http://dx.doi.org/10.5539/ijbm.v5n2p213

Edvinsson, L. (1997). Developing intellectual capital at Skandia. Long Range Planning, 20(3), 366-373. http://dx.doi.org/10.1016/S0024-6301(97)90248-X

Edvinsson, L., \& Malone, M. S. (1997). Intellectual Capital: Realizing your company's true value by finding its Hidden Brainpower, Harper Collins, New York, NY.

Fernandez, E., Montes, J. M., \& Vasquez, C. J. (2000). Typology and strategic analysis of intangible resources. A resource-based approach. Technovation, 20(2), 81-92. http://dx.doi.org/10.1016/S0166-4972(99)00115-7

Fry, L. W. (2003). Towards a theory of spiritual leadership. The Leadership Quarterly, 14(6), 693-727. http://dx.doi.org/10.1016/j.leaqua.2003.09.001

Goh, P. C. (2005). Intellectual capital performance of commercial banks in Malaysia. Journal of Intellectual Capital, 6(3), 385-396. http://dx.doi.org/10.1108/14691930510611120 
Goh, P. C., \& Lim, K. P. (2004). "Disclosing intellectual capital in company annual reports: evidence from Malaysia. Journal of Intellectual Capital, 5(3), 500-510. http://dx.doi.org/10.1108/14691930410550426

Hitt, M. A., Lee, H. U., \& Yucel, E. (2002). The importance of social capital to the management of multinational enterprises: Relational networks among Asian and Western firms. Asia Pacific Journal of Management, 19, 353-372. http://dx.doi.org/10.1023/A:1016247920461

Inkpen, A. C., \& Tsang, E. W. K. (2005). Social capital, networks, and knowledge transfer. The Academy of Management Review, 30(1), 146-165. http://dx.doi.org/10.5465/AMR.2005.15281445

Ireland, R. D., Hitt, M. A., \& Sirmon, D. G. (2003). A model of strategic entrepreneurship: the construct and its dimensions. Journal of Management, 29(6), 963-989. http://dx.doi.org/10.1016/S0149-2063(03)00086-2

Isaac, R. G., Herremans, I. M., \& Kline, T. J. (2010). Intellectual capital management enablers: a structural equation modeling analysis. Journal of Business Ethics, 93, 373.391. http://dx.doi.org/10.1007/s10551-009-0227-5

Ismail, M. B. (2005). The influence of intellectual capital on the performance of Telekom Malaysia. PhD Thesis. Universiti Teknologi Malaysia.

Jorgensen, K.M. (2006). Conceptualising intellectual capital as language game and power. Journal of Intellectual Capital, 7(1), 78-92. http://dx.doi.org/10.1108/14691930610639787

Khalique, M. \& Isa, A. H. b. M. (2014). Intellectual capital in SMEs Operating in Boutique Sector in Kuching Malaysia The IUP Journal of Management Research, 13 (2), 17-28.

Khalique, M. (2012). Impact of Intellectual Capital on the Organizational Performance of Selected Small and Medium Enterprises in Malaysia and Pakistan PhD Thesis, Universiti Malaysia Sarawak.

Khalique, M., Isa, A. H. b. M., \& Shaari, J. A. N. b. (2013). Predicting the Impact of Intellectual Capital Management on the Performance of SMEs in Electronics Industry in Kuching, Sarawak. The IUP Journal of Knowledge Management, 11(4), 53-61.

Khalique, M., Isa, A. H. B. M., \& Shaari, J. A. N. B. (2013). Intellectual capital management a paradigm for Malaysian SMEs in Kuching, Sarawak. $3^{\text {rd }}$ Annual International Conference on Business Strategy and Organizational Behaviour (BizStrategy2013). 185-188. http://dx.doi.org/10.5176/2251-1970_BizStrategy13.34

Khalique, M., Mansor, S. A., Isa, A. H. b. M., \& Shaari, J. A. N. b. (2014). Intellectual Capital and Challenges of Organizations in the Twenty-First Century. In P. O. d. Pablos \& R. D. Tennyson (Eds.), Strategic Approaches for Human Capital Management and Development in a Turbulent Economy (pp. 91-101). Hershey, PA, USA: IGI Global.

Khalique, M., Shaari, J. A. N. b., \& Isa, A. H. b. M. (2013). The road to the development of intellectual capital theory. International Journal of Learning and Intellectual Capital, 10(2), 
122-136. http://dx.doi.org/10.1504/IJLIC.2013.052953

Khalique, M., Shaari, J. A. N. b., \& Isa, A. H. b. M. (2014). Determining the Influence of Intellectual Capital on the Organizational Performance of Banking Sector in Kelantan, Malaysia. International Journal of Learning and Intellectual Capital, 11(4).

Khalique, M., Shaari, J. A. N. b., Isa, A. H. M., \& Samad, N. B. (2013). Impact of Intellectual Capital on the Organizational Performance of Islamic Banking Sector in Malaysia. Asian Journal of Finance \& Accounting, 5(2), 75-83. http://dx.doi.org/10.5296/ajfa.v5i2.4005

Khalique, M., Shaari, J. A. N., \& Isa, A. H. Md. (2011). Intellectual capital and its major components. International Journal of Current Research, 3(6), 343-347.

Khalique, M., Shaari, J. A. N., Isa, A. H. M., \& Ageel, A. (2011). Role of intellectual capital on the organizational performance of electrical and electronic SMEs in Pakistan. International Journal of Business Management, 6(9), 253-257. http://dx.doi.org/10.5539/ijbm.v6n9p253

Khalique, M., Shaari, J. A. N., Isa, A. H. Md., \& Ageel, A. (2011). The challenges faced by the small and medium enterprises (SMEs) in Malaysia: in intellectual capital perspective. International Journal of current research, 3(6), 398-401.

Khan, M. W. J., \& Khalique, M. (2014). Entrepreneurial approach and intellectual capital in Pakistani manufacturing pharmaceutical organizations. $6^{\text {th }}$ International Borneo Business Conference, Kuching, Malaysia, (IBBC) 20-21 August, 2014.

Koka, B. R., \& Prescott, J. E. (2002). Strategic alliances as social capital: a multidimensional view. Strategic Management Journal, 23(9), 795-816. http://dx.doi.org/10.1002/smj.252

Kozak, M. (2011). Strategic approach to intellectual capital development in regions. International Journal of Learning and Intellectual Capital, 8(1), 76-93. http://dx.doi.org/10.1504/IJLIC.2011.037360

Kujansivu, P. (2009). Is there something wrong with intellectual capital management models \& quest? Knowledge Management Research and Practice, 7(4), 300-307. http://dx.doi.org/10.1057/kmrp.2009.23

Liu, A. (2008). Measuring spiritual capital a latent variable. The RM Institute, USA. Also Available at: http://www.researchmethods.org/MeasuringSpCapital.pdf

Martin-de-Castro, G., Delgado-Verde, M., Lopez-Saez, P., \& Navas-Lopez, J. (2011). Towards an intellectual capital-based view of the firm: origins and nature. Journal of Business and Ethics, 98(4), 649-662. http://dx.doi.org/10.1007/s10551-010-0644-5

Nahapiet, J., \& Ghoshal, S. (1998). Social capital, intellectual capital, and the organizational advantage. Academy of Management Review, 23(2), 242-266.

Ramezan, M. (2011). Intellectual capital and organizational organic structure in knowledge society: how are these concepts related? International Journal of Information Management, 31(1), 88-95. http://dx.doi.org/10.1016/j.ijinfomgt.2010.10.004 
Ramirez, Y. (2010). Intellectual capital models in Spanish public sector. Journal of Intellectual Capital, 11(2), 248-264. http://dx.doi.org/10.1108/14691931011039705

Roos, G., \& Roos, J. (1997). Measuring your company's intellectual capital performance. Long range planning, 30(3), 413-426. http://dx.doi.org/10.1016/S0024-6301(97)90260-0

Roos, G., Bainbridge, A., \& Jackobsen, K. (2001). Intellectual capital analysis as a strategic tool. Strategy \& Leadership, 29(4), 21-26. http://dx.doi.org/10.1108/10878570110400116

Roos, J., Roos, G., Dragonetti, N., \& Edvinsson, L. (1997). Intellectual capital: Navigating in the New Business Landscape. New York University Press, New York, NY.

Schultz, T. W. (1981). Investing in People: the Economics of Population Quality. University of California, Berkeley and Los Angeles, CA.

Shaari, J. A. N., Khalique, M., \& Isa, A. H. B. M. (2011). Ranking of public and domestic private sector commercial banks in Pakistan on the basis of intellectual capital performance. Khadim Ali Shah Bukhari Institute of Technology Business Journal, 4, 61-68.

Stewart, T. A. (1997). Intellectual capital: the new wealth of organizations, Bantam Doubleday, Dell Publishing Group, New York, NY.

Sveiby, K. E. (1997). The New Organizational Wealth: Managing and Measuring Knowledge-Based Assets. Berrette-Koehler Publishers, CA, San Francisco.

Tai-Ning, Y., Hsiao-Chen, C., Shou-Yen, L., \& Chiao-Lun, T. (2011). Knowledge creation and intellectual capital on securities investment services. African Journal of Business and Management, 5(3), 924-933.

Taliyang, S. M., Latif, R. A., \& Mustafa, N. H. (2011). The determinants of intellectual capital disclosure among Malaysia listed companies. International Journal of Management and Marketing Research, 4(3), 25-33.

Wu, W. Y., \& Tsai, H. J. (2005). Impact of social capital and business orientation mode on intellectual capital and knowledge management. International Journal of Technology Management, 30(1/2), 147-171. http://dx.doi.org/10.1504/IJTM.2005.006353

\begin{abstract}
About Author:
Muhammad Wasim Jan Khan is currently a PhD Scholar (Strategic Management) in the Faculty of Economics and Business University Malaysia Sarawak, Malaysia. He is the first researcher going to champion the concept of strategic planning in small and medium enterprises (SMEs) in Pakistani context. He is also the first author going to champion the concept of strategic planning with the intellectual capital in empirical research in Pakistani SMEs. His research interest includes strategic planning, intellectual capital, entrepreneurship and SMEs performances.
\end{abstract}

\title{
Copyright Disclaimer
}

Copyright for this article is retained by the author(s), with first publication rights granted to the journal.

This is an open-access article distributed under the terms and conditions of the Creative Commons Attribution license (http://creativecommons.org/licenses/by/3.0/). 